УДК 631.316.022

DOI https://doi.org/10.32838/2663-5941/2020.2-1/04

Voitik A. V.

Uman National University of Horticulture

Kravchenko $\boldsymbol{V} . \boldsymbol{V}$.

Uman National University of Horticulture

Kutkovetska T.O.

Uman National University of Horticulture

Pushka O.S.

Uman National University of Horticulture

\title{
ANALYSIS OF STRIP CULTIVATORS FOR TILLAGE ON THE TECHNOLOGY OF STRIP-TILL
}

The article presents the problem of choosing an aggregate for bandpass processing of soil with the condition of minimizing energy consumption. Modern cultivators for cutting strips require a large capacity of tractors per one meter of working width. This is primarily due to the large depth of tillage, but also affects the greater weight of the machines. To ensure the possibility of cutting crop residues, the weight of the cultivator must provide the necessary pressure of the disc knives to the soil. As a rule, half of this pressure is achieved by hydraulically clamping the frame of the cultivator or its sections, while the other half is directly the weight of the cultivator. Today manufacturers offer a large number of different cultivators for strip processing. All of them in general have the same working principle, but the combinations of working tools are different. This, in turn, affects the weight, productivity and power consumption. Additionally, different work bodies provide different tasks, or one task with different results, which affects the final purpose of processing and the quality of its execution. The article considers the use of different types of belt cultivators taking into account their productivity, tractor power consumption, weight and cost. Further studies require the question of the quality of the operation of cutting the strips of different sections of strip cultivators. The research methodology for choosing the optimal cultivator using the distance-to-target method and the energy evaluation of mechanized technologies in plant growing is determined. The choice of the least expensive, in terms of energy, schemes of cultivators allowed to draw conclusions about the rational arrangement of working tools in the section. If the main task is to reduce energy consumption, it is better to give preference to cultivators with disk working tools. These can be flat or wavy disks, their choice will primarily depend on the moisture content of the soil. These machines can operate at high speeds of more than 12-15 km / h, which ensures their high performance. The results of theoretical studies on the choice of strip cultivators are based on models of the world's leading manufacturers.

Key words: Cultivator, Strip-Till, disk knives, working tools, energy evaluation, mechanized technologies.

Formulation of the problem. From different crops in the crop rotation, row crops, especially those that have well-developed rod roots-ape, sugar beet, corn, sunflower - equire a lot of attention. They loosen the soil good enough and provide a good structure for further cultivation of subsequent crops. In turn, on poor soil preparation and improper handling of the precursor, they react very sensitively with significant fluctuations in yield [1, p. 263]. Given these features, along with the need to save energy and preserve the integrity of the environment in agrarian production, alternative technologies of management are gaining more importance, one of the leading places among which belongs to Strip-Till technologies [2, p. 81].
Analysis of recent research and publications. Technology comes from the United States of America. In recent years, the number of farmers who practice Strip-Till technology in the US is growing every year [3, p. 48].

For many agrarian countries, Strip-Till's system of rational soil management is new. The earth is cultivated on arable depth, and even deeper than strips, and not entirely. In the intervals between the strips, the soil remains untreated and the natural structure of the soil remains intact as in direct sowing.

However, cultivators for strip processing have been little studied. Considering the working conditions of these cultivators in different natural and climatic zones, 
it is necessary to investigate the effectiveness of their application. First of all, it is necessary to determine not only the qualitative performance of strip cultivators on soils characteristic of the central region of Ukraine, but also the energy indicators of their use [4, p. 6].

Currently, there are a lot of researches in the field of cultivator working for Strip-Till. The working tool "ROPA", is intended for minimum tillage with a strip deepening $[5$, p. $35 ; 6$. p 42]. Its curved stand has an internal soil bend in the direction of the field cut at an angle of 45 degrees and is equipped with a flat-cutting foot, a knife and a shoe with an overlaid chisel. A known cultivator working tool that can process a strip 25-35 cm wide to a depth of $37 \mathrm{~cm}$ [7, p. 867]. The unit for strip cultivation without plant residue cleansers was proposed by the developers Michael G. Kovach, Rickey L. Gerber [8, p. 2].

Producers of tillage equipment offer a rather large range of Strip-Till cultivators. These are companies such as Orthman, Kuhn, Amazone, Down, Gaspardo, Kverneland, Twin Diamond Industries, Hiniker, Sunflower. Strip-Till cultivators of these companies are of great interest when using them in conditions and soils of Ukraine.

Formulating the goals of the article. Using the distance-to-target method and the energy evaluation of mechanized technologies [9, p. 138], a study was made of the technical and technological parameters of sections of modern cultivators for strip processing of soil.

Let's compare the proposed cultivators for energy indicators. The primary data for selection and justification are the norms for the production of $\mathrm{W}_{\mathrm{zm}}$ and fuel costs for $\mathrm{H}_{\mathrm{f}}$.

All calculations lead to 1 hectare. For the shifting rate of production, the hourly rate of production $\mathrm{W}_{\mathrm{hr}}$, ha hr $r^{-1}$ is found.

The energy equivalents are determined as follows.

$$
W_{h r}=\frac{W_{z m}}{7},
$$

where $\mathrm{W}_{\mathrm{zm}}$ is the replacement rate of production, ha $\mathrm{hr}^{-1} ; 7$ is the rationary hours.

The number of hours (person-hours ha-1) is determined by the formula:

$$
H_{h r}=\frac{1}{W_{h r}},
$$

The energy intensity of the machine unit $\left(\mathrm{MJ} \mathrm{ha}^{-1}\right)$ is:

$$
E_{m u}=H_{h r}\left(a_{e f}+a_{a m}+a_{c}\right)
$$

where $a_{e f}, a_{a m}, a_{c}$ - the energy equivalent of the energy facility, the agricultural machine, the coupling, respectively, $\mathrm{MJ} \mathrm{ha}^{-1}$.

Energy consumption of fuel (MJ ha $\left.{ }^{-1}\right)$ equals:

$$
E_{f}=H_{f} \cdot a_{f},
$$

where $\mathrm{H}_{\mathrm{f}}$ - is the rate of fuel consumption $\mathrm{kg} \mathrm{ha}^{-1}$, is determined by the standards; $a_{\mathrm{f}}-$ is the energy equivalent of fuel; $\mathrm{a}_{\mathrm{f}}=79,5 \mathrm{MJ} \mathrm{kg}^{-1}$.

Expenses of the operator:

$$
3_{o}=\frac{n_{o}}{W_{h r}},
$$

where $n_{o}-$ the number of machine operators, which serve the unit in one shift.

Since there are no auxiliary workers, the total costs of the work are $3_{c}=3_{o}$.

Energy intensity of human work ( $\left.\mathrm{MJ} \mathrm{ha}^{-1}\right)$ :

$$
E_{h}=3_{o} \cdot a_{o}+3_{a d} \cdot a_{a d},
$$

Total energy consumption for the process operation:

$$
E_{c}=E_{m u}+E_{f}+E_{h},
$$

The results of the calculations are summarized in Table 1.

For the previous analysis and comparison of different Strip-Till cultivators and the definition of rational, ten brands of cultivators were taken. To solve this problem, multicriteria analysis is applied. The evaluation of alternative methods of selecting the Strip-Till cultivator was carried out using five criteria: cultivator productivity $\mathrm{W}$, ha $\mathrm{h}^{-1}(\mathrm{~K} 1)$; the power of the tractor, which is necessary for the cultivator to work (the power required for the operation of one section) $\mathrm{P}, \mathrm{kW}(\mathrm{K} 2)$; mass of cultivator (mass of one section) $\mathrm{m}, \mathrm{kg}(\mathrm{K} 3)$; energy intensity of cultivator $\mathrm{E}$, $\mathrm{MJ} \mathrm{ha}^{-1}(\mathrm{~K} 4)$; the value of the cultivator (the cost of the section) $U, \$(K 5)$. The initial set of alternative cultivator options for Strip-Till technology and the relevant criteria and their values are given in Table 2 (the number of rows is indicated in parentheses).

To perform multicriteria analysis, we used the distance-to-target method. A comparison of all variants of the original set with a conditional idealized variant is performed, in which the best values of the criteria from the original set of alternative variants are present. The formation of the set of accepted 
criteria is carried out with the same direction of improvement (reduction) of all criteria. The task of their comparative evaluation was solved by the method of prioritizing by using the coefficients of significance of the criteria $\lambda \mathrm{i}$ whose value is calculated under the condition $\Sigma \lambda \mathrm{i}=1$. For this, the criteria were compared in pairs and the coefficients of advantages are indicated in the corresponding cells of the matrix (Table 3). For this, the criteria were compared in pairs and the coefficients of advantages are indicated in the corresponding cells of the matrix $\mathrm{K} 4>\mathrm{K} 2>\mathrm{K} 1>\mathrm{K} 3=\mathrm{K} 5$.
The coefficient of significance of the criteria $\lambda_{\mathrm{i}}$ is determined by the formula:

$$
\lambda_{i}=\frac{P_{i j}}{\sum P_{i j}},
$$

where $\mathrm{P}_{i j}$ - is the sum of the products of each element of the i-th line by the elements of the vectorcolumn $\sum K_{i j}$ is defined as:

$$
P_{i j}=\left[K_{i j}\right]\left[\sum K_{i j}\right] \downarrow,
$$

Table 1

\begin{tabular}{|c|c|c|c|c|c|c|c|c|c|}
\hline \multirow[b]{2}{*}{ Brand cultivator } & \multicolumn{3}{|c|}{ Productivity } & \multirow{2}{*}{ 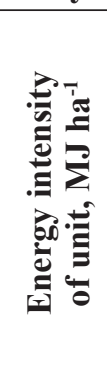 } & \multirow{2}{*}{ 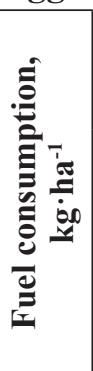 } & \multirow{2}{*}{ 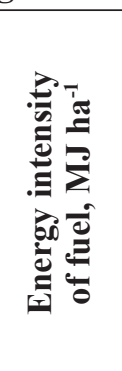 } & \multirow{2}{*}{ 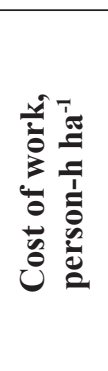 } & \multicolumn{2}{|c|}{$\begin{array}{c}\text { Energy } \\
\text { intensity, } \\
\text { MJ ha-1 }^{-1}\end{array}$} \\
\hline & 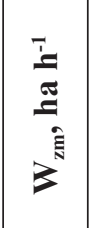 & $\frac{j}{I}$ & 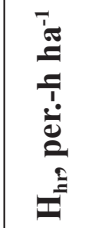 & & & & & 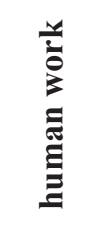 & 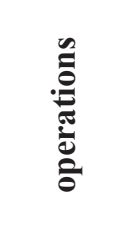 \\
\hline 1tripr (Orthmen) 8 rows & 42 & 6 & 0.17 & 67.45 & 8.7 & 691.65 & 0.17 & 7.23 & 766.33 \\
\hline Pluribus (DAWN) 6 rows & 29.4 & 4.2 & 0.24 & 42.11 & 3.8 & 302.1 & 0.24 & 10.33 & 354.54 \\
\hline Stripcat (Slyfrance) 12 rows & 70 & 10 & 0.10 & 41.72 & 4.8 & 381.6 & 0.10 & 4.34 & 427.66 \\
\hline Amazone xtill 8 rows & 46.9 & 6.7 & 0.15 & 53.27 & 6.7 & 532.65 & 0.15 & 6.48 & 592.40 \\
\hline Kuhn (Striger) 8 rows & 42 & 6 & 0.17 & 64.10 & 7.3 & 580.35 & 0.17 & 7.23 & 651.68 \\
\hline Kuhn-Krause (unit Gladiator) 12 rows & 49 & 7 & 0.14 & 50.84 & 5.7 & 453.15 & 0.14 & 6.20 & 510.19 \\
\hline Gaspardo Zebra 8 rows & 42 & 6 & 0.17 & 75.95 & 8.7 & 691.65 & 0.17 & 7.23 & 774.83 \\
\hline Kverneland Kultistrip 8 rows & 63 & 9 & 0.11 & 42.89 & 5.4 & 429.3 & 0.11 & 4.82 & 477.01 \\
\hline Hiniker 60006 rows & 50.4 & 7.2 & 0.14 & 52.61 & 6 & 477 & 0.14 & 6.03 & 535.64 \\
\hline Sunflower 76108 rows & 63 & 9 & 0.11 & 40.88 & 4.8 & 381.6 & 0.11 & 4.82 & 427.30 \\
\hline
\end{tabular}

Calculation of the energy intensity of aggregates

\begin{tabular}{|c|c|c|c|c|c|c|}
\hline \multirow[t]{2}{*}{ № } & \multirow[t]{2}{*}{ Brand cultivator } & $\begin{array}{c}\text { Productivity } \\
\mathrm{H}_{\mathrm{hr}}, \text { per.-h } \mathbf{h a}^{-1}\end{array}$ & $\begin{array}{l}\text { Tractor } \\
\text { power } \\
\mathbf{P}, \mathbf{k W} \\
\end{array}$ & Mass m, kg & $\begin{array}{l}\text { Energy intensity of } \\
\text { work } \mathrm{E}, \mathrm{MJ} \mathrm{ha}^{-1}\end{array}$ & Cost U, \$ \\
\hline & & $\left(K_{1}\right)$ & $\left(K_{2}\right)$ & $\left(K_{3}\right)$ & $\left(\mathbf{K}_{4}\right)$ & $\left(\mathbf{K}_{5}\right)$ \\
\hline 1 & Gaspardo Zebra (8) & 0.17 & 22.2 & 274 & 774.83 & 4000 \\
\hline 2 & Stripcat Twin Diamond (8) & 0.10 & 15 & 375 & 427.66 & 4160 \\
\hline 3 & Orthman 1tripr (8) & 0.17 & 22.2 & 407 & 766.33 & 4750 \\
\hline 4 & Kverneland Kultistrip (8) & 0.11 & 22.1 & 306 & 477.01 & 7250 \\
\hline 5 & Kuhn Gladiator (12) & 0.14 & 20 & 425 & 510.19 & 4375 \\
\hline 6 & Kuhn Striger (8) & 0.17 & 21 & 303 & 651.68 & 6000 \\
\hline 7 & Dawn Pluribus (6) & 0.24 & 8 & 230 & 354.54 & 5000 \\
\hline 8 & Hiniker $6000(6)$ & 0.14 & 15 & 247 & 535.64 & 3650 \\
\hline 9 & Amazone xtill (8) & 0.15 & 16 & 390 & 592.40 & 3441 \\
\hline 10 & Sunflower $7610(8)$ & 0.11 & 17 & 411 & 427.30 & 5000 \\
\hline & Idealized option (lowest) & 0.10 & 8 & 230 & 354.54 & 3441 \\
\hline
\end{tabular}

The initial set of alternatives cultivators for Strip-Till technology 
After determining the coefficients of importance criteria, calculate the distance to the target for a given set of alternatives:

$$
\mu_{i}=\Sigma\left(\frac{U_{i j}}{U_{i 0}} \lambda_{i}\right)-1,
$$

where $U_{i j}$ - is the value of the $i$-th criterion of the $\mathrm{j}$-th variant; $\mathrm{U}_{\mathrm{i} 0}$ - is the value of the $\mathrm{i}$-th criterion of the idealized variant; $\lambda_{i}-$ is the coefficient of significance of the $\mathrm{i}$-th criterion.

Table 3

\section{Matrix for determining priorities}

\begin{tabular}{|c|c|c|c|c|c|c|c|c|}
\hline \multirow{2}{*}{$\begin{array}{l}\text { Criteria } \\
\text { numbers }\end{array}$} & \multicolumn{5}{|c|}{ Criteria numbers } & \multirow[b]{2}{*}{$\sum \mathbf{K}_{\mathbf{i}}$} & \multirow[b]{2}{*}{$\mathbf{P}_{\mathrm{ij}}$} & \multirow[b]{2}{*}{$\lambda_{i}$} \\
\hline & $\mathbf{K}_{1}$ & $\mathbf{K}_{2}$ & $\mathbf{K}_{3}$ & $\boldsymbol{K}_{4}$ & $\mathbf{K}_{5}$ & & & \\
\hline $\mathrm{K}_{1}$ & 1.0 & 0.5 & 1.5 & 0.5 & 1.5 & 5 & 22 & 0.19 \\
\hline $\mathrm{K}_{2}$ & 1.5 & 1.0 & 1.5 & 0.5 & 1.5 & 6 & 27.5 & 0.24 \\
\hline $\mathrm{K}_{3}$ & 0.5 & 0.5 & 1.0 & 0.5 & 1.0 & 3.5 & 16 & 0.14 \\
\hline $\mathrm{K}_{4}$ & 1.5 & 1.5 & 1.5 & 1.0 & 1.5 & 7 & 33.75 & 0.29 \\
\hline $\mathrm{K}_{5}$ & 0.5 & 0.5 & 1.0 & 0.5 & 1.0 & 3.5 & 16 & 0.14 \\
\hline$\sum$ & & & & & & & 115.25 & \\
\hline
\end{tabular}

Outline of the main research material. The main task of mechanical tillage is to create favorable conditions for the growth and development of plants. To create such conditions, it is necessary to perform a mechanical effect on the soil by certain tillage tools.

To ensure such conditions, it is necessary to develop a classification of working tools, taking into account the severity of their work and the destruction of soil structure. Therefore, the working tools that are used in Strip-Till technology are classified according to the sequence of their work and the load on the soil [11, p. 39].

Equipment for the implementation of Strip-Till can be divided into three main categories: light, medium and heavy, depending on the weight of the sections and the depth of processing (or degree of tillage). Moreover, it is classified according to the degree of influence of the working tool on the soil.

Spring aggregates for Strip-Till are mainly intended for cleaning a number of plant residues and moderate surface loosening of the soil. It is possible at the same time to apply mineral fertilizers to the depth of surface loosening. For the autumn version of Strip-Till in the section for strip cultivation, the jay is mandatory for intensive loosening of the soil:

a) medium - for a depth of $20-30 \mathrm{~cm}$;

b) heavy - for the depth of processing 30-50 cm.

To implement these technological operations, it is necessary to use certain working tools, which, with a minimum of energy costs, make it possible to implement the full range of planned activities
Cutters - designed to guide the strip, cutting stubble residues, furrow formation, which facilitates and improves the performance of the executive working tools.

The main working tool is a stand for loosening the soil. How rippers are used: chisels, chisel-like paws.

The executive working tool is designed for processing the created strip, cropping weeds, loosening, pre-sowing soil cultivation, creating conditions for efficient fertilization, growth and development of seeds.

Section for the introduction of mineral fertilizers is intended for the introduction of mineral fertilizers.

Section for leveling the soil - is intended for leveling the field, fixing fertilizers, creating conditions for the further development of plants by compacting or loosening.

The energy analysis of cultivators made it possible to evaluate their performance taking into account the productivity (and this is the number of sections and speed of movement), mass and fuel consumption of the units.

As calculations show, the energy intensity of aggregates (Table 2) varies from $354 \mathrm{MJ} \mathrm{ha}^{-1}$ to $775 \mathrm{MJ} \mathrm{ha}^{-1}$. The lowest energy intensity of the Stripcat (Slyfrance) units is $427.66 \mathrm{MJ} \mathrm{ha}^{-1}$, Pluribus (DAWN) is $354.54 \mathrm{MJ}^{2} \mathrm{~h}^{-1}$, Kverneland Kultistrip 477.01 $\mathrm{MJ} \mathrm{ha}^{-1}$ and Sunflower 7610 - 427.3 $\mathrm{MJ} \mathrm{ha}^{-1}$.

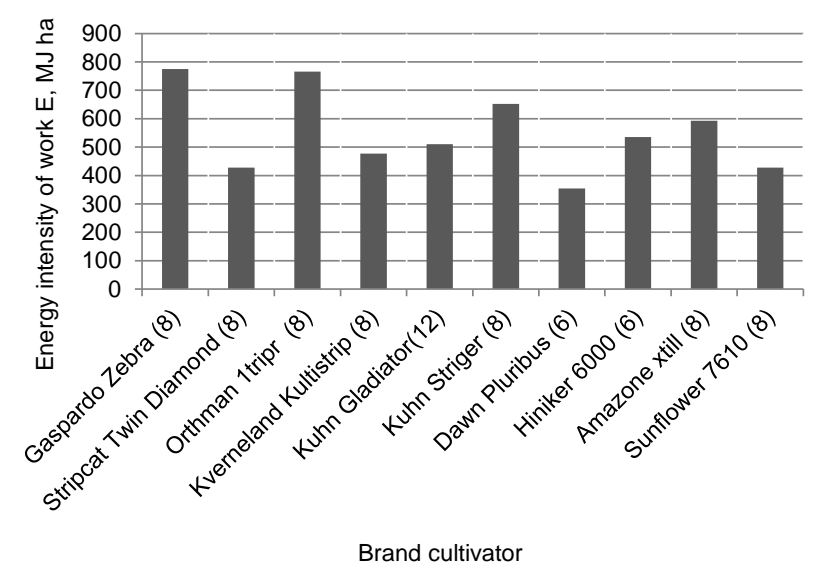

Figure 1. The graph of the energy intensity of aggregates

The largest increase of energy intensity (Fig. 1) in the Gaspardo Zebra units is $774.83 \mathrm{MJ} \mathrm{ha}^{-1}$, 1tripr (Orthman) - 766.33 MJ ha' ${ }^{-1}$, Kuhn Striger - 651.68 $\mathrm{MJ} \mathrm{ha}^{-1}$, Amazone xtill - 592.4 $\mathrm{MJ}^{\mathrm{h}}{ }^{-1}$, Hiniker 6 $000-535.64 \mathrm{MJ} \mathrm{ha}^{-1}$ and Kuhn Krause (aggregate Gladiator) - 510.19 $\mathrm{MJ} \mathrm{ha}^{-1}$. The high energy intensity is primarily due to the mass of aggregates. To cut plant residues, a large pressure of the knife (mainly discs) is needed on the soil. This pressure is created 
with the help of hydraulic systems and the weight of the cultivator sections. In addition to the mass of the most cultivators, the energy intensity is also affected by the depth of processing and the performance of working tools. Cultivators Pluribus (DAWN) and Hiniker 6000 are treated in six rows, but Pluribus (DAWN) works at a depth of 5-12 cm, and the Hiniker 6000 can operate at a depth of $30 \mathrm{~cm}$ and the energy intensity of the Hiniker 6000 is $43 \%$ more than the Pluribus (DAWN), because its aggregation requires a twice as powerful tractor.

All the cultivators considered are designed for the same purpose, so the layout of their working tools is similar, but the energy capacity of Pluribus (DAWN) is also smaller because it does not have a chisel-like paw. In all other cultivators from the group, the layout of the working tools is as follows: a disk knife is installed in front of the section, followed by a row cleaner - two star-like discs, then a chisel, scoring discs and a roller. The working bodies of machines differ both in shape and in size. And this, accordingly, already affects the working conditions of the machine and the mass of working sections. So the cultivators Sunflower 7610 and 1tripr (Orthman) are processed in 8 bands, they work almost at the same depth up to $25 \mathrm{~cm}$, have almost the same weight

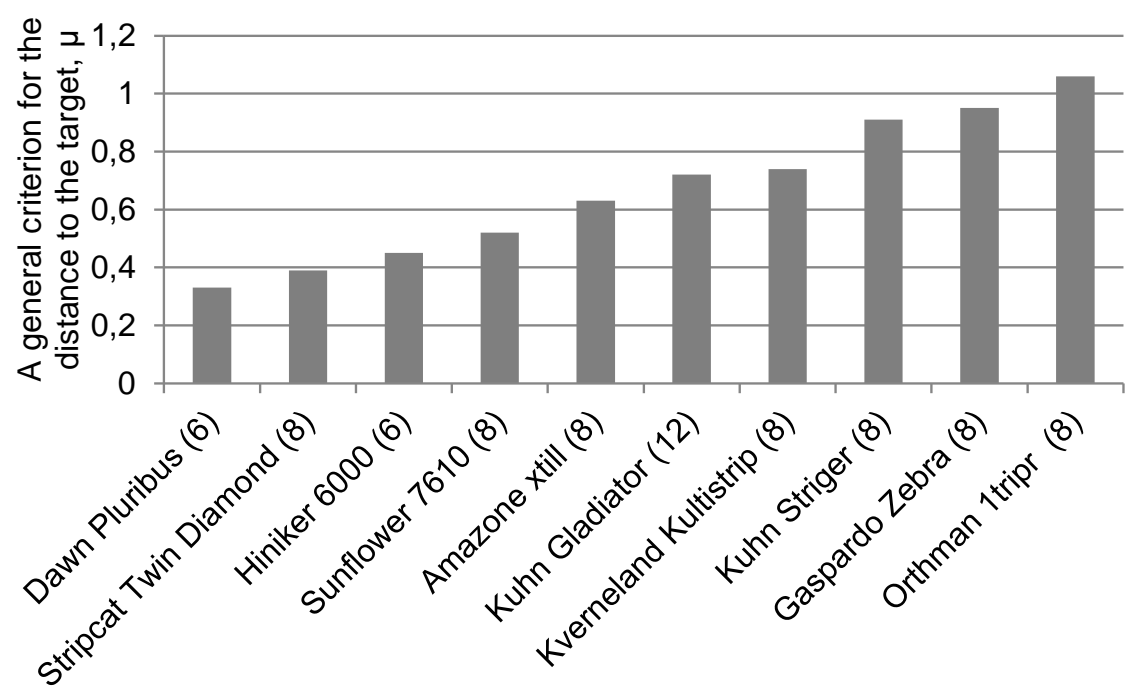

Brand cultivator

Figure 2. The graph of mechanized technology options behind the general criterion of distance to the target

Table 4

Evaluation of mechanized technology options

\begin{tabular}{|c|c|c|c|c|c|c|c|}
\hline \multirow[b]{2}{*}{ Brand cultivator } & \multicolumn{5}{|c|}{ Criteria used for analysis } & \multirow{2}{*}{\begin{tabular}{|c|} 
A general \\
criterion for \\
the distance to \\
the target, $\mu$
\end{tabular}} & \multirow{2}{*}{$\begin{array}{c}\text { Grade } \\
\text { of } \\
\text { cultiva- } \\
\text { tors }\end{array}$} \\
\hline & $\begin{array}{c}\text { Productivity } \\
\text { H }_{\mathrm{h}, \text { per.-h ha }} \text { per }^{-1}\end{array}$ & $\begin{array}{c}\text { Tractor } \\
\text { power } \mathbf{P}, \mathbf{k W}\end{array}$ & $\begin{array}{l}\text { Mass } \\
\mathrm{m}, \mathrm{kg}\end{array}$ & $\begin{array}{c}\text { Energy inten- } \\
\text { sity of work } \\
\text { E, MJ ha- }\end{array}$ & $\begin{array}{c}\text { Cost } \\
\mathbf{U}, \mathbb{\$}\end{array}$ & & \\
\hline & K1 & $\mathrm{K} 2$ & $\mathrm{~K}_{3}$ & K4 & $\mathrm{K}_{5}$ & & \\
\hline Gaspardo Zebra (8) & 0.17 & 22.2 & 274 & 774.83 & 4,000 & 0.95 & 9 \\
\hline Stripcat Twin Diamond (8) & 0.10 & 15 & 375 & 427.66 & 4,160 & 0.39 & 2 \\
\hline Orthman 1tripr (8) & 0.17 & 22.2 & 407 & 766.33 & 4,750 & 1.06 & 10 \\
\hline Kverneland Kultistrip (8) & 0.11 & 22.1 & 306 & 477.01 & 7,250 & 0.74 & 7 \\
\hline Kuhn Gladiator (12) & 0.14 & 20 & 425 & 510.19 & 4,375 & 0.72 & 6 \\
\hline Kuhn Striger (8) & 0.17 & 21 & 303 & 651.68 & 6,000 & 0.91 & 8 \\
\hline Dawn Pluribus (6) & 0.24 & 8 & 230 & 354.54 & 5,000 & 0.33 & 1 \\
\hline Hiniker $6000(6)$ & 0.14 & 15 & 247 & 535.64 & 3,650 & 0.45 & 3 \\
\hline Amazone xtill (8) & 0.15 & 16 & 390 & 592.40 & 3,441 & 0.63 & 5 \\
\hline Sunflower $7610(8)$ & 0.11 & 17 & 411 & 427.30 & 5,000 & 0.52 & 4 \\
\hline Idealized machine & 0.10 & 8 & 230 & 354.54 & 3,441 & 0.00 & \\
\hline
\end{tabular}


of the sections (411 and $407 \mathrm{~kg}$ respectively), but the aggregation of the cultivator 1tripr (Orthman) requires $30 \%$ capacity than the Sunflower 7610 (22.5 kW and $17 \mathrm{~kW}$, respectively). And the total energy intensity of these cultivators has the corresponding result: the energy intensity of the cultivator 1tripr (Orthman) is $79 \%$ higher than the energy intensity of the cultivator Sunflower. The number of sections of cultivators have their influence on the energy intensity of aggregates. It can be seen from the table that the eight-row Gaspardo Zebra has a $52 \%$ higher energy intensity than the twelverow Kuhn Krause (the Gladiator unit). Gaspardo Zebra has a smaller mass of sections (274 kg against 425 in Gladiator), a smaller depth of treatment (10-25 cm vs. $15-30 \mathrm{~cm}$ in Gladiator), but more power per section ( $22.5 \mathrm{~kW}$ vs $20 \mathrm{~kW}$ in Gladiator). The high energy intensity of Zebra is explained by the increased capacity by $12 \%$ for its aggregation, but the main role is due to the performance, because in Gladiator the performance is more by $21 \%$ than in Zebra. The greatest impact on the energy intensity of the process is the fuel consumption per unit area. Having a big grip bus and working speed Gladiator wins on this parameter. Hence the conclusion, cultivators with a large number of sections and a high working speed have an advantage over energy costs. In the future, it is necessary to investigate the operation of machines at speeds of $15 \mathrm{~km} \mathrm{~h}^{-1}$ and more as the resistance of the soil begins to increase sharply, which in turn should negatively affect the energy intensity of the process.

The multicriterion analysis which was carried out, allowed from the initial set of alternatives to choose a variant that is closer to the idealized version, for which $\mu=0$. The distance to the target determined in this way for a given set of alternative options gives a comparative evaluation of technology options (Table 4).

Thus, from Table 4 and Fig. 2 it can be seen that of the considered mechanized variants of the Striptill technology, the closest to the idealized version is the cultivator Dawn Pluribus (6), in which the general criterion of the distance to the target is 0.33 . The cultivators Stripcat Twin Diamond (8) $(\mu=0.39)$ and Hiniker $6000(6)(\mu=0.45)$ also approached the idealized variant. As we have already discussed, Dawn Pluribus treats the soil to a depth of up to $12 \mathrm{~cm}$, so it has the best result for three parameters: the capacity for aggregating one section, the mass of the section and the energy intensity of the work. Indicators of these criteria and determined the best result in relation to the idealized version. But if you look at the productivity of this machine, then it is the smallest of the group. Stripcat Twin Diamond has the best result in terms of productivity while not having the greatest energy and price. The Hiniker 6000 also has good productivity with low mass sections and price. The cultivators Orthman 1tripr $(8)(\mu=1.06)$, Gaspardo Zebra (8) $(\mu=0.95)$ and Kuhn Striger (8) $(\mu=0.91)$ were far from the idealized version. These cultivators are the most energy intensive in operation with relatively low productivity.

Conclusions. Thus, the conducted multicriteria analysis allowed to estimate cultivators for work on Strip-Till taking into account different criteria: technological, technical and economic. The depth of processing, working elements, the width of the grip, the number of sections have their influence on the efficiency of the machines. The obtained results make it possible to compare machines among themselves, but it is necessary to take into account the working conditions for which these cultivators are designed.

For example, you need to consider the depth of processing. The disks do not allow working at great depths, while the paws can process the soil and apply fertilizers to a depth of $30-35 \mathrm{~cm}$. The combination of one paw for deep processing and two or three discs is best suited for all tasks with the least energy costs. Also, the failure, if possible, of the purifiers of the rows and rollers has a positive effect on the productivity and energy intensity of the unit.

\section{References:}

1. Kalenska, S.M. et al. Systems of modern intensive technologies in plant growing. Vinnitsa : FOP Rogalskaya I.O., 2015. 458 p.

2. Bilinska, V.Modern innovative technologies in agriculture: themain characteristics and prospects of implementation. Bulletin of Taras Shevchenko National University of Kyiv. Serie “Economics”. 2015. № 7 (172). P. 81-85.

3. Moebius-Clune B.N. et.al. Comprehensive Assessment of Soil Health - The Cornell Framework. Edition 3.2. Geneva, NY : Cornell University, 2016. 123 p.

4. McGuire A.M.. High Residue Farming Under Irrigation : Strip-till. Washington State University Extension Publication, EM036E, 2014. 8 pp.

5. Borisenko, P.I. et al. Technological optimization of basic tillage. Newsletter RUDN. 2018. № 13 (1). P. $35-44$.

6. Grechkosii V.D. et al. Design of technological processes in crop production. Nigyn : PE Lysenko M.M., 2014. $392 \mathrm{p}$. 
7. Meznikova M.V. Improvement of Strip-till tillage technology with the development of a resource-saving working organ for deep striptelle. Scientific and methodical electronic magazine “Concept”. 2016. № 11. P. 876-880.

8. Patent №14/463,761. Tillage implement with scraper deflector. Michael G. Kovach, Morton, IL (US); Rick L. Gerber, Roanoke, IL (US); Eric J. Anderson, Metamora, IL (US). No.: US 2015/0053441 A1 ; filed Aug. 20, 2014 ; pub. date Feb. 26, 2015.

9. Nahirnyy, J.P. et al. Analysis of technological systems and substantiation of decisions. Kamyanets-Podilsky : FOP Sysyn, 2013. 264 p.

10. Luna J., Staben M. 2003. Using Strip Tillage in Vegetable Production Systems in Western Oregon. Oregon State University Extension Service. 12 pp.

11. Belyaev V.I. et al. Technology Strip-Till: features of design of machines of leading world manufacturers and their applications. Bulletin of the Altai State Agrarian University. 2013. Issue 11. P. 86-91.

\section{Войтік А.В., Кравченко В.В., Кутковецька Т.О., Пушка О.С. АНАЛІЗ СТРІЧКОВИХ КУЛЬТИВАТОРІВ ДЛЯ ОБРОБІТКУ ІРУНТУ ЗА ТЕХНОЛОГIÏ STRIP-TILL}

У статті наведено проблему вибору агрегату для смугової обробки трунту з умовою мінімізащіі витрат енергії. Сучасні культиватори для нарізування смуг вимагають великої потужності тракторів на один метр ширини захвату. Це насамперед пов'язано з великою глибиною обробітку трунту, але також позначається і велика вага машин. Щоб забезпечити можливість перерізання рослинних залишків, вага культиватора повинна забезпечувати необхідний тиск дискових ножів на трунт. Як правило, половина иього тику досягається шлляхом гідравлічного притискання рами культиватора чи його секиій, а інша половина - ие безпосередньо вага культиватора. Виробники натепер пропонують велику кількість різних культиваторів для смугової обробки. Всі вони загалом мають той самий принцип роботи, але комбінаиії робочих органів відрізняються. Це, своєю чергою, позначається на вазі, продуктивності й споживчій потужності. Додатково різні робочі органи забезпечують виконання різних задач, або однієї задачі з різними результатами, щьо впливає на кінцеву мету оброблення та якість його виконання. У статті розглянуто використання різних видів смугових культиваторів з урахуванням їхньої продуктивності, споживаної потужності трактора, ваги й вартості. Подальших досліджень вимагають питання якості виконання операції нарізання стрічок різними секиіями стрічкових культиваторів. Визначено методику дослідження з вибору оптимального культиватора за допомогою методу відстані до иелі й енергетичної оцінки механізованих технологій в рослинництві. Вибір найменш витратних із боку енергії схем культиваторів дозволив зробити висновки про рачіональне компонування робочих органів на секції. Якщо основне завдання стоїть у зменшенні споживання енергії, краще віддати переваги культиваторів із дисковими робочими органами. Це можуть бути плоскі або хвилясті диски, їх вибір насамперед буде залежати від вологості трунту. Такі машини можуть працювати на підвищених швидкостях, понад 12-15 км/2од, що забезпечує їхню високу продуктивність. Результати теоретичних досліджень по вибору смугових культиваторів наведені на основі моделей провідних світових виробників.

Ключові слова: культиватор, стрічка, дисковий ніж, робочий інструмент, енергооцінка, механізовані технологіï. 